\title{
Design, Synthesis and Evaluation of 4-Aminopyridine Analogues as Cholinesterase Inhibitors for Management of Alzheimer's Diseases
}

\author{
Shashi Kant Singh', Saurabh Kumar Sinha², Mrunal Krishnarao Shirsat ${ }^{\star 3}$ \\ ${ }^{1}$ Faculty of Pharmacy, Pacific Academy of Higher Education and Research University, Udaipur, Rajasthan, INDIA. \\ ${ }^{2}$ Department of Pharmaceutical Sciences, Mohanlal Sukhadia University, Udaipur, Rajasthan, INDIA. \\ ${ }^{3}$ Faculty of Pharmacy, Pacific Academy of Higher Education and Research University, Udaipur, Rajasthan, INDIA.
}

\begin{abstract}
Introduction: Alzheimer's disease (AD) is a slowly progressive devasting neurodegenerative disorder of central nervous system manifested by deterioration of memory, cognitive functions, behaviour change and impairment in performing activities of daily life. Neurochemical studies of patients suffering from AD demonstrate selective loss of cholinergic neurons, low concentration of acetylcholine (Ach) in the selective areas of brain such as cortex and hippocampus. Objective: A series of new semicarbazones of 4-aminopyridine has been designed, synthesized and evaluated for cognition enhancing activities through the inhibition of acetylcholinesterase (AChE) and by passive avoidance model. Material and methods: In the present study, ten new 4-Aminopyridine analogues were synthesized and characterized by analytic methods such as UV, IR, NMR, elemental analysis and for their inhibitory role on Acetylcholinesterase activity by applying the molecular docking studies and performed enzyme kinetics study by Ellman's spectrophotometric method. The synthesized analogues were then evaluated for antiamnesic and cognition enhancing activities by passive avoidance test. Results: The results illustrated a significant cognition enhancing effect on passive avoidance test with a significant reversal of scopolamine-induced amnesia, which is comparable with standard drug rivastigmine. The in-vitro study of synthesized analogues showed maximum activity of compound-3 and compound-9 compared to standard drug rivastigmine, whereas its enzyme kinetic study revealed a non-competitive inhibition of acetylcholinesterase ( $\mathrm{AChE}$ ) is held responsible to a possible interaction of analogue with the peripheral anionic site (PAS) of AChE and was also confirmed by molecular docking studies. Conclusion: On the basis of present study, we are concluding that hydroxyl substituted Compound 3 and 9 identified as most potent drug which can leads to the discovery and development of new Cognition enhancers in near future.
\end{abstract}

Key words: 4-aminopyridine, Acetylcholinesterase, Passive avoidance test, Rivastigmine.

\section{INTRODUCTION}

Alzheimer's disease (AD) is a slowly progressive devasting neurodegenerative disorder of central nervous system manifested by deterioration of memory, cognitive functions, behaviour change and impairment in performing activities of daily life. ${ }^{1}$ Neurochemical studies of patients suffering from $\mathrm{AD}$ demonstrate selective loss of cholinergic neurons, low concentration of acetylcholine
(Ach) and choline acetyltransferase in the selective areas of brain such as cortex and hippocampus. ${ }^{2,3}$ According to World Alzheimer Report, around 47 million people were reported to have dementia in 2016 with a global cost of $\$ 818$ billion. At present, it is considered to be the sixth largest cause of death in the United States. The most promising approach to design
Submission Date: 26-09-2017; Revision Date: 08-11-2017; Accepted Date: 18-04-2018

DOI: 10.5530/ijper.52.4.75 Correspondence: Mrunal Krishnarao Shirsat, Faculty of Pharmacy, Pacific Academy of Higher Education and Research University, Udaipur, Rajasthan-313024, INDIA Phone: +918233336151 E-mail: mrunalvir@gmail.com

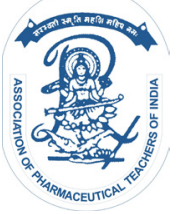

www.ijper.org 
some new cognitive enhancer based on the function of cholinergic nervous system to improve cholinergic neurotransmission achieved by preventing biotransformation of Ach at the specific areas of brain, on the basis of this approach some acetylcholinesterase inhibitors which are capable of suppressing the normal degradation of Ach in the synoptic cleft, have been established to increase the concentration of Ach and used to treat the AD. ${ }^{4,5}$ Collective interpretation of the different molecular docking and dynamic studies on different AChE inhibitors suggest that active centre of human acetylcholinesterase contains various domains like an esteratic site and an anionic site and the allosteric modulation of hAChE catalytic activity is possible through binding of some ligands at the peripheral anionic site (PAS) constituted by amino acid residues Tyr-341, Trp-286, Glu-285, Tyr-124 and Tyr-72.6,7 Presently, 4-aminopyridine (4AP) analogues are under intensive investigation due to their antiacetylcholinesterase activity which has shown promising effects in eliminating memory related dysfunctions. ${ }^{8}$ Several amides and imides derivatives of $m$-aminobenzoic acid and $p$-aminobenzoic acid have been synthesized and evaluated for their anticholinesterase activity, which suggested that, parasubstituted derivatives are prominently active than their meta and ortho-substituted derivatives, ${ }^{9,10}$ Numerous Schiff bases of styrylpyridine and carbamate analogues of 4AP and have been synthesized and evaluated for their anticholinesterase activity. ${ }^{11,12}$ Some 2-indolinone analogues of $4 \mathrm{AP}$ and 4-aminobutyric acid (GABA) have been also reported to possess antiamnesic activity. ${ }^{13}$ The hydrazone analogues of dihydropyridine and indolinones have also been reported to elicit potent anticholinesterase and antibutyrylcholinesterase activity. ${ }^{14,15}$ Several N-benzylpiperidine-purine, 3-Methylpyridinium, Novel Oximes, Phenitidine Derivatives, Phenyl Benzamide Derivatives and 2-thionaphthol analogues of berberine have evaluated for $\mathrm{AChE}$ and $\mathrm{BChE}$ inhibitory activity. ${ }^{16,17,18,19,20} \mathrm{AD}$ is associated with aging and more prone to geriatric persons. Since, humans and rats exhibit similar age-related alterations therefore, ${ }^{21,22,23}$ estimation of age-related cognitive impairment and spatial memory deficit in aged rats may provide more beneficial information associated to humans. ${ }^{24}$ Keeping these facts in considerations, we synthesized and evaluated some new 4AP analogues as potential antiamnesic and cognition enhancing agents.

\section{MATERIALS AND METHODS}

All the chemicals used in the experiment were of analytical grade purity and were purchased from Sigma-Aldrich
(India). Rivastigmine was obtained as a gift sample from Sun Pharmaceutical Industries Ltd (Silvassa, India). The Melting point of the synthesized analogues was determined in open capillary tube by using Stuart melting point apparatus and was uncorrected. The reaction progress was monitored by thin layer chromatography with chloroform: methanol (6:4) as the mobile phase on TLC silica gel 60 F254 aluminium sheets obtained from Merck Company and activated at $110^{\circ} \mathrm{C}$ for $10 \mathrm{~min}$. Iodine was used for the colour visualization of the spots. UV spectral analysis was performed on JASCO (Model 7800) UV-VIS spectrophotometer. FTIR spectra were obtained on a Shimadzu FTIR Version 8400S at the scanning range of $400-4000 \mathrm{~cm}^{-1} \cdot{ }^{1} \mathrm{H}$ and ${ }^{13} \mathrm{C}$ NMR spectra were obtained in deuterated chloroform and deuterated dimethylsulfoxide as solvent and are recorded in parts per million (ppm) downfield from Tetramethylsilane (Me4Si) as internal reference by using JEOL AL Version 300 FT-NMR spectrophotometer. Elemental analysis was performed using Exeter CE-440 elemental analyzer.

\section{Experimental details}

The syntheses of semicarbazide of 4-aminopyridine analogues were carried out using the procedures as given in Scheme.

Scheme: Semicarbazones of 4-aminopyridine.
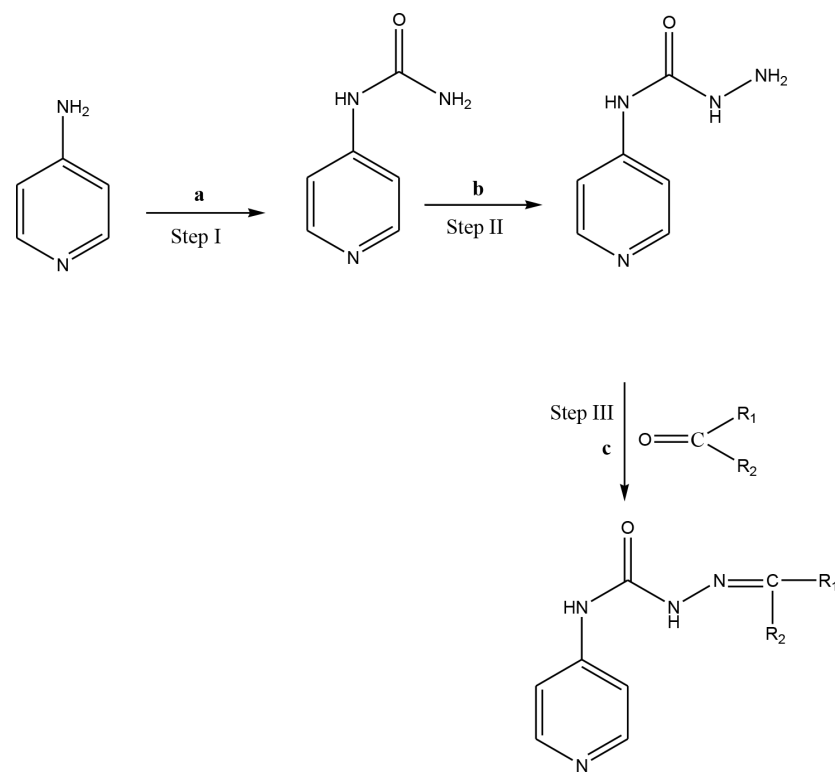

Scheme: The synthetic pathway of 1-10. (a) NACNO, glacial acetic acid, 4 h. (b) $\mathrm{NH}_{2} \mathrm{NH}_{2} \cdot \mathrm{H}_{2} \mathrm{O}, \mathrm{C}_{2} \mathrm{H}_{5} \mathrm{OH}$, $\mathrm{NaOH}, 3$ h. (c) $\mathrm{C}_{2} \mathrm{H}_{5} \mathrm{OH}$, glacial acetic acid, $2 \mathrm{~h}$.

\section{1-(pyridin-4-yl) urea (intermediate-1)}

4-Aminopyridine $(0.01 \mathrm{~mol})$ was dissolved in mixture containing $5 \mathrm{ml}$ of glacial acetic acid and $25 \mathrm{ml}$ with distilled water. Equimolar $(0.01 \mathrm{~mol})$ quantity of $\mathrm{NaCNO}$ in $25 \mathrm{ml}$ 
of warm water was added with continuous stirring, the reaction mixture was allowed to stand for $4 \mathrm{~h}$ and the product was obtained by filtration, washed with water, dried in an oven below melting point and recrystallized from ethanol to afford key intermediate- $1,{ }^{25}$ Yield: 86.0\%, mp:212-214 ${ }^{\circ} \mathrm{C}, \mathrm{R}_{\mathrm{f}} 0.65$, IR $\left(\mathrm{KBr}, \mathrm{vcm}^{-1}\right)$ : 3431, $(\mathrm{NH}), 3325,3122$ (doublet $\left.\mathrm{NH}_{2}\right), 1678(\mathrm{C}=\mathrm{O}), 1588$, $1579(\mathrm{C}=\mathrm{N}), 1474\left(\mathrm{C}=\mathrm{C}\right.$, aromatic); ${ }^{1} \mathrm{H}$ NMR (DMSO-do) ( $\delta$ ppm): 8.91 (bs, $1 \mathrm{H}, \mathrm{NH}), 8.39$ (d, 2H, pyridine), 6.78 (d, $2 \mathrm{H}$, pyridine), 6.54 (s, $\left.2 \mathrm{H}, \mathrm{NH}_{2}\right) ;{ }^{13} \mathrm{C}$ NMR $(\delta \mathrm{ppm})$ : $169.43(\mathrm{C}=\mathrm{O}), 154.27,150.10,109.48$ (pyridine); Anal. Calcd. (\%) for $\mathrm{C}_{6} \mathrm{H}_{7} \mathrm{~N}_{3} \mathrm{O}: \mathrm{C}$ 52.55, $\mathrm{H}$ 5.14, N 30.64; found (\%) C 52.35, H 5.23, N 30.57.

\section{4-(pyridin-4-yl) semicarbazide ((intermediate-2)}

Intermediate- $1 \quad(0.01 \mathrm{~mol})$ and hydrazine hydrate $(0.01 \mathrm{~mol})$ were dissolved in $5 \mathrm{ml}$ of ethanol and refluxed for $3 \mathrm{~h}$ in presence of sodium hydroxide $(0.01 \mathrm{~mol})$. The precipitate was obtained by filtration, washed with water, dried in an oven below melting point and recrystallized from ethanol to afford key intermediate- $2,{ }^{26}$ Yield: 82.3\%, mp: $230-232^{\circ} \mathrm{C}, \mathrm{R}_{\mathrm{f}} 0.50$, IR $\left(\mathrm{KBr}, \mathrm{ucm}^{-1}\right)$ : 3431 , $(\mathrm{NH}), 3325,3122$ (doublet $\mathrm{NH}_{2}$ ), $1678(\mathrm{C}=\mathrm{O}), 1588$, $1579(\mathrm{C}=\mathrm{N}), 1474$ (C=C, aromatic); ${ }^{1} \mathrm{H}$ NMR (DMSO-d 6 ) ( $\delta \mathrm{ppm}): 10.48,9.31$ (bs, 2H, NH), 8.36 (d, 2H, pyridine), 6.78 (d, 2H, pyridine), 6.54 (s, $\left.2 \mathrm{H}, \mathrm{NH}_{2}\right) ;{ }^{13} \mathrm{C} \mathrm{NMR}$ ( $\delta \mathrm{ppm}): 159.14(\mathrm{C}=\mathrm{O}), 154.32,150.66,109.42$ (pyridine); Anal. Calcd. (\%) for $\mathrm{C}_{6} \mathrm{H}_{8} \mathrm{~N}_{4} \mathrm{O}$ : C 47.36, $\mathrm{H}$ 5.30, N 36.82; found (\%) C 47.17, H 5.25, N 36.89.

\section{General procedure for the synthesis of compounds (1-10)}

Equal moles of intermediate- $2(0.456 \mathrm{~g}, 0.003 \mathrm{~mol})$ in $5 \mathrm{ml}$ of ethanol mixed with equal moles of the different aldehyde or ketone was refluxed for $2 \mathrm{hrs}$ and glacial acetic acid was added to adjust the $\mathrm{pH}$ of the reaction between 5-6. The solid obtained after cooling was filtred, dried and crystallized from $95 \%$ ethanol to afford compounds $(1-10){ }^{27}$

\section{1-(2, 4, 6-trihydroxybenzylidene)-4-(pyridin-4-yl) semicarbazide (compound-1)}

Yield: $82.3 \%$, mp: $230-232^{\circ} \mathrm{C}, \mathrm{R}_{\mathrm{f}} 0.50$, IR $\left(\mathrm{KBr}, \mathrm{ucm}^{-}{ }^{1}\right)$ : $3515(\mathrm{OH}), 3432,3325(\mathrm{NH}), 1677(\mathrm{C}=\mathrm{O}), 1589,1578$ $(\mathrm{C}=\mathrm{N}), 1473\left(\mathrm{C}=\mathrm{C}\right.$, aromatic); ${ }^{1} \mathrm{H}$ NMR (DMSO-d6) ( $\delta$ ppm): 11.5 (s, 3H, OH), 10.16, 10.10 (bs, 2H, NH), 8.38 (d, 2H, pyridine), 7.99 (s, $1 \mathrm{H}, \mathrm{N}=\mathrm{CH}), 7.38(\mathrm{~m}$, $2 \mathrm{H}$, aromatic), $6.56\left(\mathrm{~d}, 2 \mathrm{H}\right.$, pyridine); ${ }^{13} \mathrm{C}$ NMR $(\delta \mathrm{ppm})$ : $167.54(\mathrm{C}=\mathrm{O}), 153.15(\mathrm{~N}=\mathrm{CH}), 155.31,150.48,109.17$ (pyridine), 137.70, 130.68, 129.39, 128.10 (aromatic); Anal. Calcd. (\%) for $\mathrm{C}_{11} \mathrm{H}_{9} \mathrm{~N}_{4} \mathrm{O}_{3}$ : C 53.88, $\mathrm{H}$ 3.70, N 22.85; found (\%)C 53.57, H 3.74, N 22.80.

\section{1-(2, 4-dimethoxybenzylidene)-4-(pyridin-4-yl) semicarbazide (compound-2)}

Yield: $82.3 \%, \mathrm{mp}: 230-232^{\circ} \mathrm{C}, \mathrm{R}_{\mathrm{f}} 0.50$, IR $\left(\mathrm{KBr}, \mathrm{ucm}^{-}{ }^{-}\right)$: 3431, $3325(\mathrm{NH}), 3062\left(\mathrm{CH}, \mathrm{CH}_{3}\right), 1677(\mathrm{C}=\mathrm{O}), 1589$, $1578(\mathrm{C}=\mathrm{N}), 1473$ (C=C, aromatic); ${ }^{1} \mathrm{H}$ NMR (DMSO-do) $(\delta \mathrm{ppm}): 10.36,9.48(\mathrm{bs}, 2 \mathrm{H}, \mathrm{NH}), 8.40(\mathrm{~d}, 2 \mathrm{H}$, pyridine), 7.95 (s, $1 \mathrm{H}, \mathrm{N}=\mathrm{CH}), 7.29-7.53$ (m, 3H, aromatic), 6.60 (d, $2 \mathrm{H}$, pyridine), 4.20 (s, $\left.6 \mathrm{H}, \mathrm{CH}_{3}\right) ;{ }^{13} \mathrm{C}$ NMR $(\delta \mathrm{ppm})$ : $169.39(\mathrm{C}=\mathrm{O}), 153.84(\mathrm{~N}=\mathrm{CH}), 155.34,150.67,109.17$ (pyridine), 137.60, 130.29, 129.14, 128.13 (aromatic), $55.90\left(\mathrm{CH}_{3}\right)$; Anal. Calcd. (\%) for $\mathrm{C}_{15} \mathrm{H}_{16} \mathrm{~N}_{4} \mathrm{O}_{3}: \mathrm{C} 62.21$, H 5.22, N 20.73; found (\%) C 62.15, H 5.20, N 20.66.

\section{1-(4-hydroxy-3, 5-dimethoxybenzylidene)-4- (pyridin-4-yl) semicarbazide (compound-3)}

Yield: $82.3 \%$, mp:230-232 ${ }^{\circ} \mathrm{C}, \mathrm{R}_{\mathrm{f}} 0.50, \mathrm{IR}\left(\mathrm{KBr}, \mathrm{ucm}^{-1}\right)$ : $3515(\mathrm{OH}), 3431,3325(\mathrm{NH}), 1677(\mathrm{C}=\mathrm{O}), 1589,1578$ $(\mathrm{C}=\mathrm{N}), 1473\left(\mathrm{C}=\mathrm{C}\right.$, aromatic); ${ }^{1} \mathrm{H}$ NMR (DMSO-do) $(\delta \mathrm{ppm}): 10.80$ (s, 1H, OH), 9.85, 9.52 (bs, 2H, NH), 8.36 (d, $2 \mathrm{H}$, pyridine), 7.92 (s, $1 \mathrm{H}, \mathrm{N}=\mathrm{CH}), 7.66,7.59$ ( $\mathrm{m}, 2 \mathrm{H}$, aromatic), $6.58\left(\mathrm{~d}, 2 \mathrm{H}\right.$, pyridine), $4.26\left(\mathrm{~s}, 6 \mathrm{H}, \mathrm{CH}_{3}\right)$; ${ }^{13} \mathrm{C}$ NMR $(\delta \mathrm{ppm}): 168.44(\mathrm{C}=\mathrm{O}), 156.18(\mathrm{~N}=\mathrm{CH})$, 154.68, 150.31, 109.44 (pyridine), 139.84, 130.44, 129.18, 128.11 (aromatic), $55.89\left(\mathrm{CH}_{3}\right)$; Anal. Calcd. (\%) for $\mathrm{C}_{15} \mathrm{H}_{16} \mathrm{~N}_{4} \mathrm{O}_{4}$ : C 56.96, $\mathrm{H}$ 5.10, $\mathrm{N}$ 17.71; found (\%) C 56.76, H 5.13, N 17.78.

\section{1-(4-methoxyphenyl) ethylidene)-4-(pyridin-4-yl) semicarbazide (compound-4)}

Yield: $82.3 \%, \mathrm{mp}: 230-232^{\circ} \mathrm{C}, \mathrm{R}_{\mathrm{f}} 0.50, \mathrm{IR}\left(\mathrm{KBr}, \mathrm{vcm}^{-}{ }^{1}\right)$ : 3431, $3325(\mathrm{NH}), 3063\left(\mathrm{CH}, \mathrm{CH}_{3}\right), 1677(\mathrm{C}=\mathrm{O}), 1589$, $1578(\mathrm{C}=\mathrm{N}), 1473$ (C=C, aromatic); ${ }^{1} \mathrm{H}$ NMR (DMSO-do) ( $\delta \mathrm{ppm}): 10.54,8.56$ (bs, $2 \mathrm{H}, \mathrm{NH}), 8.34$ (d, $2 \mathrm{H}$, pyridine), 7.56-7.23 (m, 4H, aromatic), 6.57 (d, $2 \mathrm{H}$, pyridine), 1.18, 4.34 (s, $\left.6 \mathrm{H}, \mathrm{CH}_{3}\right) ;{ }^{13} \mathrm{C}$ NMR $(\delta \mathrm{ppm}): 169.23(\mathrm{C}=\mathrm{O})$, $155.00(\mathrm{~N}=\mathrm{C}), 154.35,150.45,109.19$ (pyridine), 139.66, 130.84, 129.77, 128.20 (aromatic), 24.34, $55.69\left(\mathrm{CH}_{3}\right)$; Anal. Calcd. (\%) for $\mathrm{C}_{15} \mathrm{H}_{16} \mathrm{~N}_{4} \mathrm{O}_{2}$ : C 63.37, H 5.67, N 19.71; found (\%) C 63.48, H 5.69, N 19.65.

\section{1-(4-methoxyphenyl) propylidene)-4-(pyridin-4-yl) semicarbazide (compound-5)}

Yield: $82.3 \%$, mp:230-232 ${ }^{\circ} \mathrm{C}, \mathrm{R}_{\mathrm{f}} 0.50, \mathrm{IR}\left(\mathrm{KBr}, \mathrm{ucm}^{-1}\right)$ : 3431, $3325(\mathrm{NH}), 3063,2940\left(\mathrm{CH}, \mathrm{CH}_{3}\right), 1677(\mathrm{C}=\mathrm{O})$, 1589, $1578(\mathrm{C}=\mathrm{N}), 1473$ (C=C, aromatic); ${ }^{1} \mathrm{H}$ NMR (DMSO-do) ( $\delta \mathrm{ppm}): 10.56,8.55$ (bs, 2H, NH), 9.54 (d, $2 \mathrm{H}$, pyridine), 7.60-7.39 ( $\mathrm{m}, 4 \mathrm{H}$, aromatic), $6.58(\mathrm{~d}, 2 \mathrm{H}$, pyridine), 1.16, $4.36\left(\mathrm{~s}, 6 \mathrm{H}, \mathrm{CH}_{3}\right), 1.60\left(\mathrm{~s}, 2 \mathrm{H}, \mathrm{CH}_{2}\right)$; ${ }^{13} \mathrm{C} \mathrm{NMR}(\delta \mathrm{ppm}): 169.25(\mathrm{C}=\mathrm{O}), 155.10(\mathrm{~N}=\mathrm{C}), 154.34$, 150.48, 109.17 (pyridine), 139.64, 130.82, 129.69, 128.00 (aromatic), $24.36\left(\mathrm{CH}_{2}\right), 8.20,55.67\left(\mathrm{CH}_{3}\right)$; Anal. Calcd. (\%) for $\mathrm{C}_{16} \mathrm{H}_{18} \mathrm{~N}_{4} \mathrm{O}_{2}$ : C 64.41, $\mathrm{H}$ 6.08, $\mathrm{N}$ 18.78; found (\%)C 64.37, H 6.11, N 18.64. 
1-(4-methoxyphenyl) (phenyl) methylene)-4(pyridin-4-yl) semicarbazide (compound-6)

Yield: $82.3 \%, \mathrm{mp}: 230-232^{\circ} \mathrm{C}, \mathrm{R}_{\mathrm{f}} 0.50$, IR $\left(\mathrm{KBr}, \mathrm{vcm}^{-1}\right)$ : 3431, $3325(\mathrm{NH}), 2940\left(\mathrm{CH}, \mathrm{CH}_{3}\right), 1677(\mathrm{C}=\mathrm{O}), 1589$, $1578(\mathrm{C}=\mathrm{N}), 1473\left(\mathrm{C}=\mathrm{C}\right.$, aromatic); ${ }^{1} \mathrm{H}$ NMR (DMSO-do) ( $8 \mathrm{ppm}): 10.58,9.58$ (bs, 2H, NH), 8.37 (d, 2H, pyridine), 7.68-7.10 (m, 9H, aromatic), 6.60 (d, $2 \mathrm{H}$, pyridine), 4.32 (s, $\left.3 \mathrm{H}, \mathrm{CH}_{3}\right) ;{ }^{13} \mathrm{C}$ NMR $(\delta \mathrm{ppm}): 169.15(\mathrm{C}=\mathrm{O}), 157.67$ $(\mathrm{N}=\mathrm{C}), 154.18,150.32,109.54$ (pyridine), 139.24, 130.56, 128.10 (aromatic), $55.68\left(\mathrm{CH}_{3}\right)$; Anal. Calcd. (\%) for $\mathrm{C}_{20} \mathrm{H}_{18} \mathrm{~N}_{4} \mathrm{O}_{2}$ : C 69.35, H 5.24, N 16.17; found (\%) C 69.38, H 5.22, N 16.11.

\section{1-bis (4-methoxyphenyl) methylene)-4-(pyridin-4- yl) semicarbazide (compound-7)}

Yield: $82.3 \%, \mathrm{mp}: 230-232^{\circ} \mathrm{C}, \mathrm{R}_{\mathrm{f}} 0.50$, IR $\left(\mathrm{KBr}, \mathrm{ucm}^{-1}\right)$ : 3431, $3325(\mathrm{NH}), 2941\left(\mathrm{CH}, \mathrm{CH}_{3}\right), 1677(\mathrm{C}=\mathrm{O}), 1589$, $1578(\mathrm{C}=\mathrm{N}), 1473\left(\mathrm{C}=\mathrm{C}\right.$, aromatic); ${ }^{1} \mathrm{H}$ NMR (DMSO-do) ( $\delta$ ppm): 10.86, 9.57 (bs, 2H, NH), 8.34 (d, 2H, pyridine), $7.70-7.12(\mathrm{~m}, 8 \mathrm{H}$, aromatic), $6.59(\mathrm{~d}, 2 \mathrm{H}$, pyridine), 4.34 (s, $\left.6 \mathrm{H}, \mathrm{CH}_{3}\right) ;{ }^{13} \mathrm{C}$ NMR $(\delta \mathrm{ppm}): 168.17$ $(\mathrm{C}=\mathrm{O}), 157.69(\mathrm{~N}=\mathrm{C}), 154.17,150.30,109.51$ (pyridine), 139.26, 130.50, 128.13 (aromatic), $55.70\left(\mathrm{CH}_{3}\right)$; Anal. Calcd. (\%) for $\mathrm{C}_{21} \mathrm{H}_{20} \mathrm{~N}_{4} \mathrm{O}_{3}$ : C 67.01, H 5.36, N 14.88; found (\%)C 67.11, H 5.39, N 14.84.

\section{1-(4-hydroxydiphenyl (phenyl)methylene)-4- (pyridin-4-yl) semicarbazide (compound-8)}

Yield: $82.3 \%$, mp: $230-232^{\circ} \mathrm{C}, \mathrm{R}_{\mathrm{f}} 0.50$, IR $\left(\mathrm{KBr}, \mathrm{ucm}^{-1}\right)$ : $3516(\mathrm{OH}), 3431,3326(\mathrm{NH}), 1677$ (C=O), 1589, 1578 $(\mathrm{C}=\mathrm{N}), 1473\left(\mathrm{C}=\mathrm{C}\right.$, aromatic); ${ }^{1} \mathrm{H}$ NMR (DMSO-do)

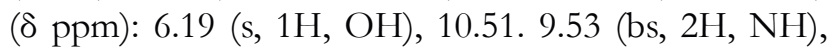
8.43 (d, 2H, pyridine), 7.54-7.40 (m, 9H, aromatic), 6.76 (d, 2H, pyridine); ${ }^{13} \mathrm{C}$ NMR ( $\left.\delta \mathrm{ppm}\right): 169.71(\mathrm{C}=\mathrm{O})$, $156.54(\mathrm{~N}=\mathrm{C}), 154.30,150.12,109.11$ (pyridine), 130.27, 129.61, 128.11 (aromatic); Anal. Calcd. (\%) for $\mathrm{C}_{19} \mathrm{H}_{16} \mathrm{~N}_{4} \mathrm{O}_{2}$ : C 68.66, H 4.85, N 16.86; found $(\%) \mathrm{C}$ 68.56, H 4.81, N 16.88.

\section{1-bis (4-hydroxyphenyl) methylene)-4-(pyridin-4-yl) semicarbazide (compound-9)}

Yield: $82.3 \%$, mp: $230-232^{\circ} \mathrm{C}, \mathrm{R}_{\mathrm{f}} 0.50$, IR $\left(\mathrm{KBr}, \mathrm{vcm}^{-1}\right)$ : $3515(\mathrm{OH}), 3431,3326(\mathrm{NH}), 1677(\mathrm{C}=\mathrm{O}), 1589,1578$ $(\mathrm{C}=\mathrm{N}), 1473\left(\mathrm{C}=\mathrm{C}\right.$, aromatic); ${ }^{1} \mathrm{H}$ NMR (DMSO- $d \sigma$ ) ( $\delta$ ppm): 9.61 (s, 2H, OH), 10.51. 9.52 (bs, 2H, NH), 8.44 (d, 2H, pyridine), 7.52-7.48 (m, $8 \mathrm{H}$, aromatic), 6.74 (d, 2H, pyridine); ${ }^{13} \mathrm{C}$ NMR ( $\left.\delta \mathrm{ppm}\right): 169.73(\mathrm{C}=\mathrm{O})$, $156.49 \quad(\mathrm{~N}=\mathrm{C}), 154.31,150.14,109.13$ (pyridine), 130.28, 129.59, 128.14 (aromatic); Anal. Calcd. (\%) for $\mathrm{C}_{19} \mathrm{H}_{16} \mathrm{~N}_{4} \mathrm{O}_{3}$ : C 65.51, H 4.63, N 16.08; found $(\%) \mathrm{C}$ 65.56, H 4.69, N 16.13 .

\section{1-(2, 4-dimethoxyphenyl) (4-hydroxyphenyl) methylene-4-(pyridin-4-yl) semicarbazide (compound-10)}

Yield: $82.3 \%$, mp: $230-232^{\circ} \mathrm{C}, \mathrm{R}_{\mathrm{f}} 0.50$, IR $\left(\mathrm{KBr}, \mathrm{ucm}^{-1}\right)$ : $3516(\mathrm{OH}), 2943\left(\mathrm{CH}, \mathrm{CH}_{3}\right), 3431,3326(\mathrm{NH}), 1677$ $(\mathrm{C}=\mathrm{O}), 1589,1578(\mathrm{C}=\mathrm{N}), 1473$ (C=C, aromatic); ${ }^{1} \mathrm{H}$ NMR (DMSO-do) ( $\left.\delta \mathrm{ppm}\right): 9.50$ (s, $\left.1 \mathrm{H}, \mathrm{OH}\right), 10.52$, 9.52 (bs, 2H, NH), 8.44 (d, 2H, pyridine), 7.53-7.42 (m, $7 \mathrm{H}$, aromatic), 6.75 (d, $2 \mathrm{H}$, pyridine), $4.34\left(\mathrm{~s}, 6 \mathrm{H}, \mathrm{CH}_{3}\right)$; ${ }^{13} \mathrm{C}$ NMR $(\delta \mathrm{ppm}): 168.17(\mathrm{C}=\mathrm{O}), 157.64(\mathrm{~N}=\mathrm{CH})$, $154.16,150.29,109.56$ (pyridine), 139.23, 130.54, 129.13, 128.11 (aromatic), 55.69 $\left(\mathrm{CH}_{3}\right)$; Anal. Calcd. (\%) for $\mathrm{C}_{21} \mathrm{H}_{20} \mathrm{~N}_{4} \mathrm{O}_{4}$ : C 64.28, H 5.14, N 14.28; found (\%) C 64.33, H 5.17, N 14.37.

\section{Biological studies}

\section{Estimation of cholinesterase activity (in-vitro)}

Ellman's spectrophotometric analysis was used to determine $\mathrm{IC}_{50}$ values. ${ }^{28}$ This method is based on the reaction between synthetic substrate acetylthiocholine iodide (ATChI) and 5,5-dithio-bis-(2-nitrobenzoicacid) (DTNB) to produce a yellow colour (5-mercapto-2-nitrobenzoicacid) which was detected by Colorimeter. The $\mathrm{IC}_{50}$ values was determined by recording the rate of increase in the absorbance at $412 \mathrm{~nm}$ for $5 \mathrm{~min}$. Prepared stock solution of AChE by dissolving AChE in $0.1 \mathrm{M}$ phosphate buffer ( $\mathrm{pH}$ 8). The final solution for assay is included $0.1 \mathrm{M}$ phosphate buffer $(\mathrm{pH} 8.0)$ with the addition of $340 \mathrm{mM}$ 5,5-dithio-bis (2-nitrobenzoic acid) (DTNB), 0.02 unit $/ \mathrm{mL}$ of $\mathrm{AChE}$ and $550 \mathrm{mM}$ of substrate (acetylthiocholine iodide, ATChI). Different concentrations of test compounds (inhibitors) between $20 \%$ and $80 \%$ ) were selected in order to obtain inhibition of the enzymatic activity. From the inhibitors (synthesized analogues) solution $(50 \mu \mathrm{L})$, increasing concentrations of the inhibitors were added to the assay solution. For this assay blank consisted of all the components except AChE. Further, the percent inhibition due to the presence of increasing concentrations of inhibitor was calculated after comparing the reaction rates which was analyzed in triplicate and determined $\mathrm{IC}_{50}$ values graphically by means of $\log$ concentration percent inhibition curves. ${ }^{29,30}$

\section{Enzyme kinetics study}

The Ellman's spectrophotometric analysis was used to identify the type of inhibition in this study. Acetylthiocholine iodide was used as a substrate in different concentrations, both below and above, near to $\mathrm{K}_{\mathrm{m}}$ in a phosphate buffer at $\mathrm{pH} 8$, with a definite concentration of acetylcholinesterase in the absence or presence of 
various inhibitors. The concentration of the inhibitors was kept close to one that corresponds to $\mathrm{IC}_{50}$ value of enzyme inhibition. Further, their inhibitory kinetics were evaluated by the Lineweaver and Burk method. ${ }^{31}$

\section{Animals}

Charles foster rats of albino strain (4 to 5 months old and 150 to $200 \mathrm{~g}$ in weight) of either sex were procured from Central Animal House, Faculty of Pharmacy, Pacific academy of higher education and research university Udaipur (Registration No. 1622/PO/a/12/CPCSEA). Six animals were housed per cage with food and water available ad-libitum at constant temperature $\left(25^{\circ} \mathrm{C} \pm 1^{\circ} \mathrm{C}\right)$ and relative humidity (45-55\%) under twelve $\mathrm{h}$ of light and dark cycles in a fully ventilated room.

\section{Acute toxicity evaluation}

The guidelines proposed by OECD (425) was used for determining acute toxicity studies of the analogues. ${ }^{32}$ In this study, nulliparous, non-pregnant, healthy female albino rats weighing between 150-200 gm were fasted overnight with water ad-libitum prior to test. On the experimental day, analogues were administered at graded dose up to $100 \mathrm{mg} / \mathrm{kg}$ p.o. in $0.3 \%$ carboxymethyl cellulose as vehicle. The animals were constantly monitored for $30 \mathrm{~min}, 2 \mathrm{~h}$ and $48 \mathrm{~h}$ so that any change in autonomic or behavioural reactions could occur and also for convulsions, salivation, lacrimation, sleep, diarrhoea, heart rate, blood pressure, pulse rate, and feeding behaviour as a sign of acute toxicity.

\section{Drug treatment}

The synthesized analogues and standard rivastigmine were suspended in $0.3 \%$ carboxymethyl cellulose and was administered orally at a dose of $3 \mathrm{mg} / \mathrm{kg}$ and $6 \mathrm{mg} / \mathrm{kg}$. All animals in the control groups were treated with $0.3 \%$ carboxymethyl cellulose equivalent to experimental drugs.

\section{Passive avoidance task}

The apparatus consists of two identical light and dark compartment with grid floors which can be electrified separately, where a guillotine door connects the two compartments. During the training trial, each rat was placed in the light compartment and after $10 \mathrm{~s}$, the door was raised. As soon as the animal was placed with all four paws in the dark compartment, the door gets automatically closed and an electrical foot shock ( $0.02 \mathrm{~mA} / 10 \mathrm{~g}$ body weight) lasting $2 \mathrm{~s}$ was delivered. The time elapsed by the rat being placed in light and entering the dark compartment was recorded as training trial entry latency time. Retention trial was performed $24 \mathrm{~h}$ after the training trial, following the similar procedure except that, the electric shock was not given and entry into the dark compartment was measured. The synthesized analogues and rivastigmine were suspended in $0.3 \%$ carboxymethyl cellulose and were administered orally 90 min before the training session and the amnesic drug was injected immediately after the conclusion of the training session. The maximum entry latency allowed in the retention session was $120 \mathrm{s.}^{33,34}$

\section{Molecular docking}

All molecules of inhibitory activities were taken and sketched 3D structures using Maestro 9.3 and geometrically reduced with the help of Macromodel 9.9 based on OPLS-2005 force field. The crystal structure of AChE was obtained from the protein data bank, pdb code: 1B41 (Average R-value 0.234, Resolution $2.8 \mathrm{~A}^{\circ}$ ). ${ }^{35}$ The structure was prepared by using Maestro 9.3, including addition of hydrogens, assigning partial charges, protonation states, restrained, partial energy minimization and the resulting structure was used as the receptor model. Crystallographic and trajectory water molecules, ions and ligand compounds were removed from the receptor structure. Proteins were prepared by using Maestro 9.3 and the Glide XP algorithm was employed. All the structures were fitted in binding pocket and the lowest energy pose for each docking run was retained. ${ }^{36}$

\section{RESULTS AND DISCUSSION}

\section{Chemistry}

4-aminopyridine reacts with sodium cyanate in the presence of glacial acetic acid formed 4-aminopyridineurea (intermediate-1), which on condensed with hydrazine hydrate in the presence of sodium hydroxide yielded the 4-aminopyridine semicarbazide (intermediate-2). The Semicarbazones (1-10) were synthesized by treating with the various aldehyde or ketone with 4-aminopyridine semicarbazide as comprised in Scheme (Table1). The purity of synthesized analogues was confirmed by TLC and characterised by FT-IR, ${ }^{1} \mathrm{H}$ NMR, ${ }^{13} \mathrm{C}$ NMR and elemental analysis. The IR, peak of $\mathrm{C}=\mathrm{N}$ and $\mathrm{NH}$ stretching vibrations was observed at $1588 \mathrm{~cm}^{-1}$ and $3431-3325 \mathrm{~cm}^{-1}$ respectively. In ${ }^{1} \mathrm{H}$ NMR spectra, intermediate- 1 and intermediate- 2 showed peak at $\delta 6.54 \mathrm{ppm}$ due to the presence of $-\mathrm{NH}_{2}$ proton. Compounds (1-3) showed peak at $\delta$ 7.92-7.99 $\mathrm{ppm}$, reflecting the presence of $\mathrm{N}=\mathrm{CH}$ proton, While a total disappearance of peak at $\delta$ 7.92-7.99 ppm in compounds (4-10) where this single proton was substituted by different groups, resulted in the formation of $\mathrm{N}=\mathrm{C}$ bond due to which confirmed the substitution. The ${ }^{13} \mathrm{C}$ NMR values of $\delta 153-157$ ppm also confirmed the formation of $\mathrm{N}=\mathrm{CH}$ and $\mathrm{N}=\mathrm{C}$ bond. 


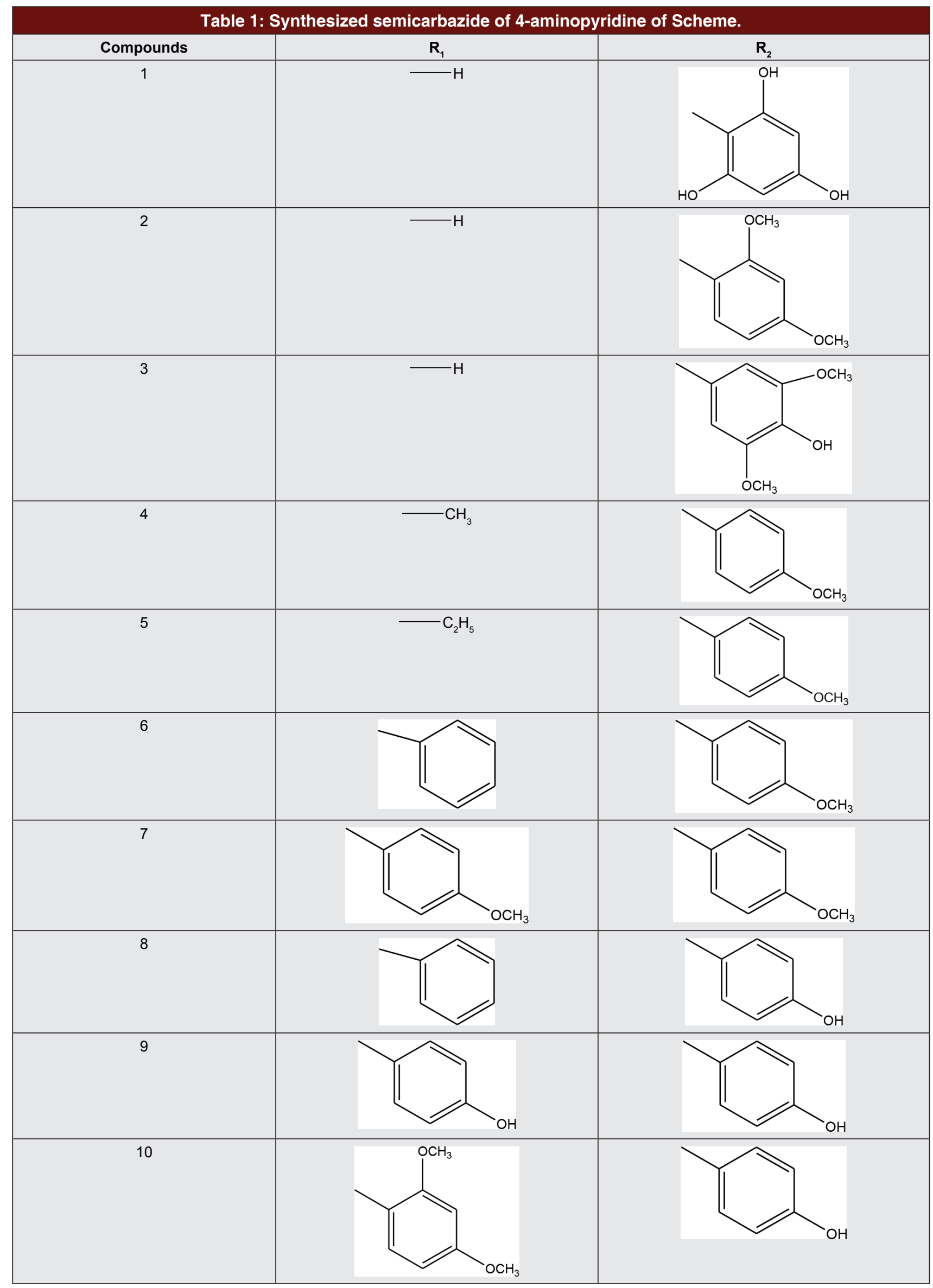




\begin{tabular}{|c|c|c|c|}
\hline \multirow{2}{*}{ Compound } & AChE & AChE & \multirow{2}{*}{ Inhibition } \\
\hline & $I C_{50}(\mu M) \pm$ SEM & $\mathrm{Ki}(\mu \mathrm{M}) \pm \mathrm{SEM}$ & \\
\hline 1 & $10.2 \pm 1.75$ & $18.27 \pm 1.480$ & $c$ \\
\hline 2 & $8.24 \pm 0.60$ & $16.54 \pm 0.66$ & $c$ \\
\hline 3 & $6.32 \pm 1.50$ & $11.23 \pm 0.84$ & $n c$ \\
\hline 4 & $24.5 \pm 1.55$ & $50.25 \pm 1.26$ & $c$ \\
\hline 5 & $6.44 \pm 0.60$ & $7.84 \pm 0.42$ & $c$ \\
\hline 6 & $32.71 \pm 0.76$ & $41.89 \pm 0.84$ & $n c$ \\
\hline 7 & $22.6 \pm 0.65$ & $25.84 \pm 0.80$ & $c$ \\
\hline 8 & $11.7 \pm 0.60$ & $20.35 \pm 0.94$ & $n c$ \\
\hline 9 & $5.58 \pm 0.016$ & $6.44 \pm 0.65$ & $n c$ \\
\hline 10 & $6.85 \pm 0.76$ & $9.36 \pm 0.76$ & $n c$ \\
\hline Rivastigmine* & $6.15 \pm 0.57$ & $130.9 \pm 0.6$ & $c$ \\
\hline
\end{tabular}

$c=$ competitive, $n c=$ noncompetitive.

\section{Biological activity In vitro AChE Inhibition}

AChE inhibitory activity of the all synthesized analogues was determined by using Ellman spectrophotometric method. ${ }^{28}$ The nature of $\mathrm{AChE}$ inhibition was elucidated by performing enzyme kinetics study of all synthesized analogues. The inhibitory concentration of synthesized analogues (IC50) to inhibit acetylcholinesterase was calculated by using Graph Pad Prism. All the analogues exhibited moderate to excellent $\mathrm{IC}_{50}$ values. The $\mathrm{IC}_{50}$ values of compounds 3 and 9 are $6.32 \pm 1.50 \mu M$ and $5.58 \pm 0.016 \mu M$ respectively with respect to standard rivastigmine $(6.15 \pm 0.57 \mu M)$. Further, enzyme kinetics study, ${ }^{31}$ was also performed for all synthesized analogues to get information on the nature of their inhibition (Table 2). The most active compounds 3 and 9 demonstrated a non-competitive inhibition for AChE $(\mathrm{Ki}=11.23 \pm 0.84$ and $6.44 \pm 0.65$ respectively $)$ enzyme (Table 2). The non-competitive inhibition, ${ }^{34}$ is held responsible to a possible interaction of analogue with the peripheral anionic site (PAS) of AChE and it was also confirmed by docking studies.

\section{Passive avoidance test}

The synthesized analogues were then evaluated for antiamnesic and cognition enhancing activities by passive avoidance test. ${ }^{38}$ In this test, animals received punishment when it enters the dark room during the training session and thus remembers it in the session on the following day, unless their memory is impaired due to the amnesic drug. Pre-treatment with tested compounds resulted in elevate entry latency as compared to control group in significant and dose dependant manner, indicating convenient learning process. A prolonged latency indicates that the animal remembers that it has been punished and therefore, does avoid the darken chamber. The effect of inhibitors compound $\mathbf{3}$ and compound $\mathbf{9}$ on changes in entry latency in scopolamine-induced amnesia showed significant differences $[p<0.05]$ among treated groups (Table 3). Post-hoc analysis revealed that scopolamine $(1.5 \mathrm{mg} / \mathrm{kg})$ significantly $[p<0.05]$ decreased entry latency as compared to control group indicating amnesia. The inhibitors compound 3, 9 and rivastigmine, dose dependently reversed scopolamineinduced decrease in entry latency.

\section{Molecular docking}

Docking studies were carried out to provide a better interpretation of the biological profile of compound 3 and 9 toward AChE. It was found that compound $\mathbf{3}$ and $\mathbf{9}$ were properly positioned into the enzyme valley and showed interaction with the internal amino acid residue Tyr-334 and Trp-279 through a $\pi-\pi$ interaction. The study clearly demonstrated that both compounds 
Table 3: Effect of synthesized derivative and rivastigmine on cognition enhancing and scopolamine-induced amnesia on rat passive avoidance test.

\begin{tabular}{|c|c|c|c|}
\hline \multirow{2}{*}{$\begin{array}{c}\text { Treatment } \\
\text { [Dose }(\mathrm{mg} / \mathrm{kg})]\end{array}$} & \multicolumn{3}{|c|}{ Entry latency (s) } \\
\hline & Training trial & Retention trial & $\Delta$ \\
\hline Control & $17.83 \pm 0.60$ & $95.50 \pm 0.76$ & 77.67 \\
\hline $3(3.0)$ & $20.72 \pm 0.49$ & $153.62 \pm 0.66^{a}$ & 132.9 \\
\hline $3(6.0)$ & $21.54 \pm 0.57$ & $161.84 \pm 0.47^{a}$ & 140.3 \\
\hline $5(3.0)$ & $18.33 \pm 0.66$ & $118.68 \pm 0.66^{a}$ & 100.35 \\
\hline $5(6.0)$ & $18.47 \pm 0.60$ & $136.42 \pm 0.60^{a}$ & 117.95 \\
\hline $9(3.0)$ & $16.60 \pm 0.60$ & $175.62 \pm 0.76^{a}$ & 159.02 \\
\hline $9(6.0)$ & $15.65 \pm 0.98$ & $205.84 \pm 0.66^{a}$ & 190.19 \\
\hline Riva (3.0) & $14.63 \pm 0.60$ & $184.56 \pm 0.57^{a}$ & 169.93 \\
\hline Riva (6.0) & $14.96 \pm 0.76$ & $200.84 \pm 0.66^{a}$ & 185.88 \\
\hline $\operatorname{SCP}(1.5)$ & $20.00 \pm 0.63$ & $35.17 \pm 0.60^{\mathrm{a}}$ & 15.17 \\
\hline $3(3.0)+\operatorname{SCP}(1.5)$ & $20.83 \pm 0.60$ & $82.17 \pm 0.60^{b}$ & 61.34 \\
\hline $3(6.0)+\mathrm{SCP}$ & $20.17 \pm 0.60$ & $86.33 \pm 0.66^{b}$ & 66.16 \\
\hline $5(3.0)+\mathrm{SCP}$ & $21.00 \pm 0.63$ & $89.83 \pm 0.60^{b}$ & 68.83 \\
\hline $5(6.0)+\mathrm{SCP}$ & $20.33 \pm 0.80$ & $84.83 \pm 0.60^{b}$ & 64.5 \\
\hline $9(3.0)+\mathrm{SCP}$ & $19.50 \pm 0.76$ & $90.17 \pm 0.60^{b}$ & 70.67 \\
\hline $9(6.0)+\mathrm{SCP}$ & $16.67 \pm 0.49$ & $98.00 \pm 0.63^{b}$ & 81.33 \\
\hline Riva (3.0) +SCP & $19.00 \pm 0.63$ & $89.83 \pm 0.60^{b}$ & 70.83 \\
\hline Riva (6.0) +SCP & $17.17 \pm 0.60$ & $97.67 \pm 0.49^{b}$ & 80.5 \\
\hline
\end{tabular}

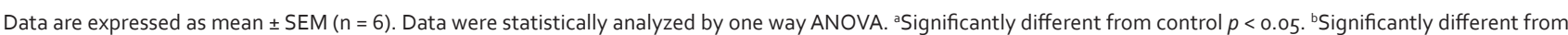
scopolamine treated group $p<0.05$. SCP $=$ Scopolamine

$\Delta=$ Difference between Retention trial and Training trial, Riva= Rivastigmine.
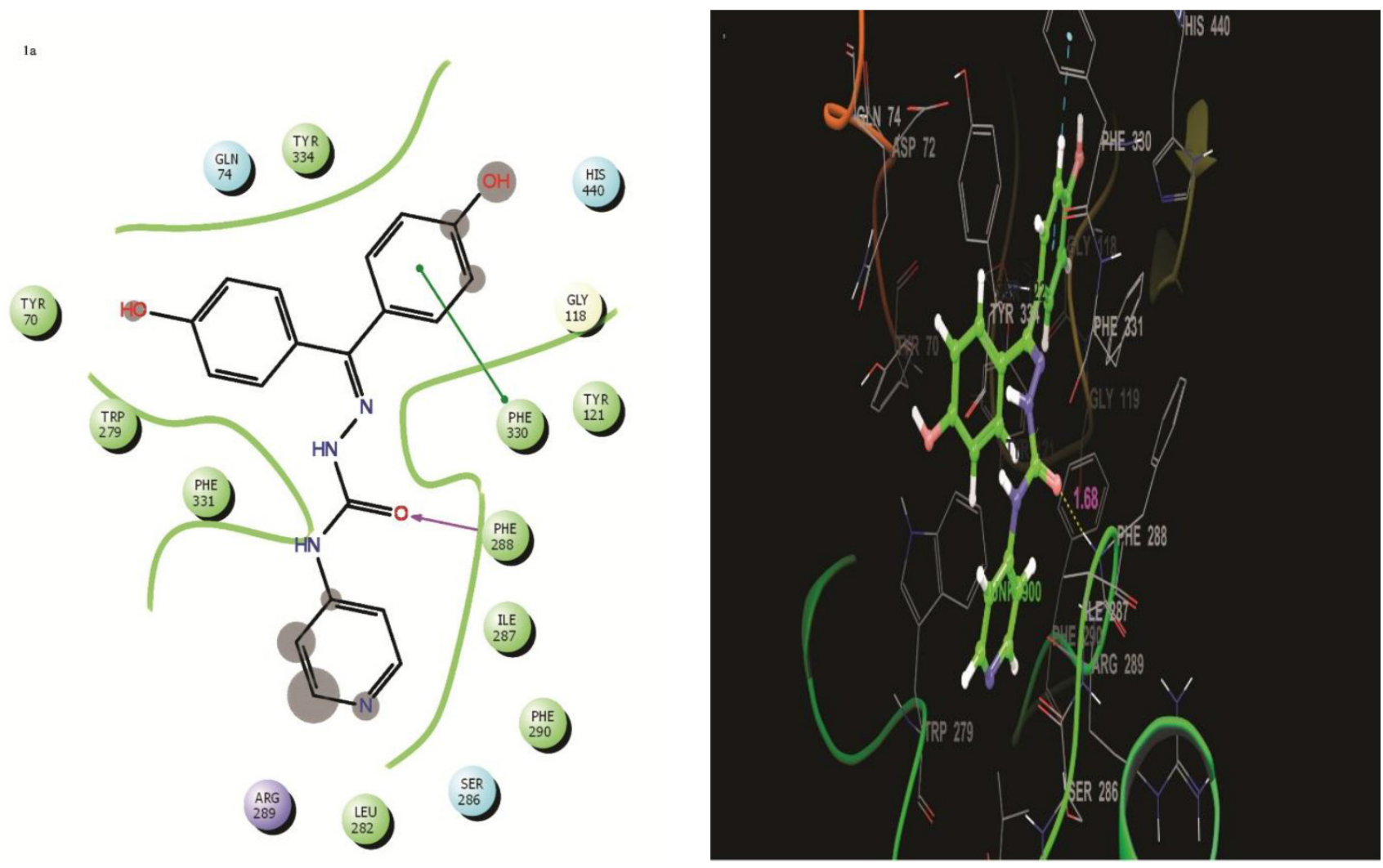

Figure 1: Molecular docking of compound 9 into the active sites of AChE (1a-2D, 1b-3D). Ligand is in green colour, dotted show H-bond interaction. 

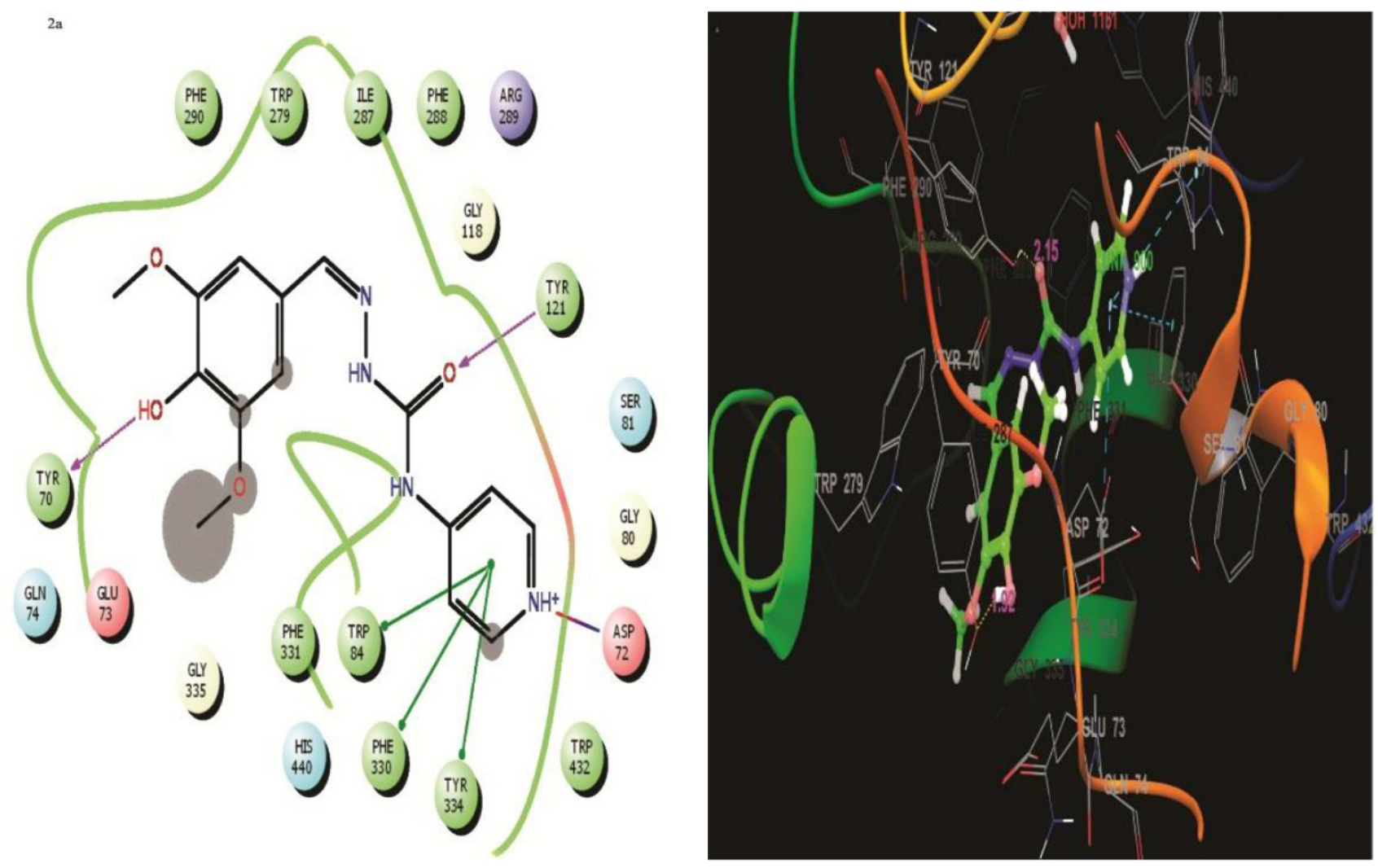

Figure 2: Molecular docking of compound 3 into the active sites of AChE (2a. 2D, 2b. 3D). Ligand is in green colour, dotted show H-bond interaction

were able to bind with the key peripheral anionic site (PAS) residue Trp-279, Tyr-334, Phe-330 and Phe-288. The carbonyl oxygen of compound $\mathbf{3}$ and $\mathbf{9}$ were involved in forming a hydrogen bond with Phe-290 and Phe-288 respectively (determine substrate specificity). The hydroxyl oxygen of compound $\mathbf{3}$ was involved in forming a hydrogen bond with Tyr-70 suggested that the compounds might probably act via the AChE inhibition. (Figure 1and 2)

\section{CONCLUSION}

From the above study, it was concluded that the hydroxyl substituted compounds $\mathbf{3}$ and $\mathbf{9}$ demonstrated a comparable activity with that of rivastigmine. In docking studies, the hydroxyl group of one of the phenyl rings of these compounds was observed establishing $\mathrm{H}$-bond with Tyr-70 which plays a dual role in the active centre: (a) its hydroxyl appears to maintain the functional orientation of Phe-288 and Tyr-70 by hydrogen bonding and (b) its aromatic moiety maintains the functional orientation of the anionic subsite Trp-84. AChE inhibition and passive avoidance test of compound $\mathbf{3}$ and $\mathbf{9}$ identified as most potent drug which can leads to the discovery and development of new Cognition enhancers in near future.

\section{ACKNOWLEDGEMENT}

The authors are thankful to Varanasi College of Pharmacy, Varanasi and Faculty of Pharmacy, Pacific Academy of Higher Education \& Research University, Udaipur for support and facilities.

\section{CONFLICT OF INTEREST}

The authors declare no conflict of interest.

\section{ABBREVIATIONS}

AChE: acetylcholinesterase; BChE: butyrylcholinesterase; hAChE: human acetylcholinesterase; AD: Alzheimer's disease; PAS: peripheral anionic site; $\mathrm{IC}_{50}$, half-maximal inhibitory concentration.

\section{REFERENCES}

1. Kaur K, Kaur R, Kaur M. Recent Advances in Alzheimer's disease: Causes and Treatment. Int J Pharm Pharm Sci. 2016;8(2): 8-15.

2. Perry EK, Perry RH, Blessed G, Tomlinson BE. Changes in brain cholinesterases in senile dementia of alzheimer type. Neuropathol Appl Neurobiol.1978;4(4):273-7.

3. Gil-Bea FJ, Garcia-Alloza M, Dominguez J, Marcos B, Ramirez MJ. Evaluation of cholinergic markers in Alzheimer's disease and in a model of cholinergic deficit. Neurosci Lett. 2005;375(1):37-41. 
4. Hakansson L. Mechanism of action of cholinesterase inhibitors in Alzheimer's disease. Acta Neurol Scand Suppl. 1993;88(S149):7-9.

5. Lahiri DK, Farlow MR, Greig NH, Sambamurti K. Current drug targets for Alzheimer's disease treatment. Drug Dev Res. 2002;56(3):267-81.

6. Barak D, Kronman C, Ordentlich A, Naomi A, Bromberg A, Marcus D, et al. Acetylcholinesterase peripheral anionic site degeneracy conferred by amino acid arrays sharing a common core. J Biol Chem. 1994;269(9):6296-05.

7. Bourne $Y$, Taylor $P$, Radic $Z$, Marchot $P$. Structural insights into ligand interactions at the acetylcholinesterase peripheral anionic site. EMBO J. 2003;22(1):1-12.

8. Sinha SK, Shrivastava SK. Synthesis, evaluation and molecular dynamics study of some new 4-aminopyridine semicarbazones as an antiamnesic and cognition enhancing agents. Bioorg Med Chem. 2013;21(17):5451-60.

9. Correa-Basurto J, Alcantara IV, Espinoza-Fonseca LM, Trujillo-Ferrara JG. p-Aminobenzoic acid derivatives as acetylcholinesterase inhibitors. Eur $\mathrm{J}$ Med Chem. 2005;40(7):732-5.

10. Trujillo-Ferrara J, Cano LM, Espinoza-Fonseca M. Synthesis. Anticholinesterase activity and structure-activity relationships of m-Aminobenzoic acid derivatives. Bioorg Med Chem Lett. 2003;13:1825-27.

11. Cavallito CJ, Yun HS, Edwards ML, Foldes FF. Choline acetyltransferase inhibitors. Styrylpyridine analogs with nitrogen-atom modifications. J Med Chem. 1971;14(2):130-3.

12. Scipione L, DeVita D, Musella A, Flammini L, Bertoni S, Barocelli E. 4-Aminopyridine derivatives with anticholinesterase and antiamnesic activity. Bioorg. Med Chem Lett. 2008;18(1):309-12.

13. Andreani A, Leoni A, Locatelli A, Morigi R, Rambaldi M, Pietra C, et al. 4-Aminopyridine derivatives with antiamnesic activity. Eur J Med Chem. 2000;35(1):77-82.

14. Alptuzun V, Prinz M, Horr V, Scheiber J, Radacki K, Fallarero A, et al. Interaction of (benzylidene-hydrazono)-1, 4-dihydropyridines with betaamyloid, acetylcholine, and butyrylcholine esterases. Bioorg Med Chem. 2010;18(5):2049-59.

15. Campagna F, Catto M, Purgatorio R, Altomare C D, Carotti A, De Stradis A, et al. Synthesis and biophysical evaluation of arylhydrazono-1H-2-indolinones as $\beta$-amyloid aggregation inhibitors. Eur J Med Chem. 2011;46(1):275-84.

16. Rodríguez-Franco MI, Fernández-Bachiller M I,Pérez C,Castro A, Martínez A. Design and synthesis of $\mathrm{N}$-benzylpiperidine-purine derivatives as new dual inhibitors of acetyl- and butyrylcholinesterase. Bioorg Med Chem. 2005;13(24):6795-802.

17. Huang L, Luo Z, He F, Lu J, Li X. Synthesis and biological evaluation of a new series of berberine derivatives as dual inhibitors of acetylcholinesterase and butyrylcholinesterase. Bioorg Med Chem. 2010;18(12):4475-84.

18. Mohammadi-Farani A, Darbandi SS, Aliabadi A. Synthesis and Acetylcholinesterase Inhibitory Evaluation of 4-(1, 3-Dioxoisoindolin-2-yl)N-Phenyl Benzamide Derivatives as Potential Anti-Alzheimer Agents. Iran J Pharm Res. 2016;15(3):313-20.ss

19. Abbasi MA, Saeed A, Aziz-ur-Rehman KM, Ashraf M, Ejaz SA. Synthesis of Brominated 2-Phenitidine Derivatives as Valuable Inhibitors of Cholinesterases for the Treatment of Alzheimer's disease. Iran J Pharm Res. 2014;13(1):87-94.

20. Hosseini SA, Moghimi A, Iman M, Ebrahimi F. Docking Studies, Synthesis, and In-vitro Evaluation of Novel Oximes Based on Nitrones as Reactivators of Inhibited Acetylcholinesterase. Iran J Pharm Res. 2017;16(3):880-92.
21. Fischer W, Chen KS, Gage FH, Bjorklund A. Progressive decline in spatial learning and integrity of forebrain cholinergic neurons in rats during aging. Neurobiol Aging. 1992;13(1):9-23.

22. Fischer W, Gage FH, Bjorklund A. Degenerative changes in forebrain cholinergic nuclei correlate with cognitive impairments in aged rats. Eur $\mathrm{J}$ Neurosci. 1989;1(1):34-45.

23. Flood DG, Coleman PD. Neuron numbers and sizes in aging brain: Comparisons of human, monkey, and rodent data. Neurobiol Aging. 1988;9:453-63.

24. Barnes CA. Memory changes with age: neurobiological correlates. In: Learning and memory: A biological view: Neurobiology of Learning and Memory. 2nd Ed. New York: Academic Press. 1991;259-96.

25. Dains FB, Wertheim E. The Action of Ammonia and Amines on the Substituted Ureas and Urethanes. Allophanic Ester. 1920;42(11):2303-09.

26. Pandeya SN, Aggarwal N, Jain JS. Evaluation of semicarbazones for anticonvulsant and sedative hypnotic properties. Pharmazie. 1999;54(4):300-02.

27. Pandeya SN, Yogeeswari P, Stables JP. Synthesis and anticonvulsant activity of 4-bromophenyl substituted aryl semicarbazones. Eur J Med Chem. 2000;35(10):879-86

28. Ellman GL, Courtney KD, Andres V Jr, Feather-Stone RM. A New and rapid colorimetric determination of acetylcholinesterase activity. Biochem Pharmacol. 1961;7(2):88-95.

29. Belluti F, Piazzi L, Bisi A, Gobbi S, Bartolini M, Cavalli A, et al. synthesis and evaluation of benzophenone derivatives as novel acetylcholinesteraseinhibitors. Eur J Med Chem. 2009;44(3):134-8.

30. Zdrazilova P, Stepankova S, Komers K, Ventura K, Cegan AZ. Half-inhibition concentrations of new cholinesterase inhibitors. Naturforsch. 2004; 59: 293-96.

31. Lineweaver $\mathrm{H}$, Burk $\mathrm{D}$. The determination of enzyme dissociation constants. J Am Chem Soc. 1934;56(3):658-66.

32. Organization for Economic Co-operation and Development (OECD) OECD guide lines for the testing of chemicals-425(Acute oral toxicity up and down procedure). 2006. Available from: http://www.oecd.org.

33. Jarvik ME, Kopp R. An improved one-trial passive avoidance learning situation. Psychol Rep. 1967;21:221-4.

34. Khromova I, Voronina T, Kraineva VA, Zolotov N, Mannisto PT. Effects of selective catechol-O-methyltransferase inhibitors on single-trial passive avoidance retention in male rats. Behav Brain Res. 1997;86(1):49-57.

35. Kryger G, Harel M, Giles K, Toker L, Velan B, Lazar A, et al. Structures of recombinant native and $\mathrm{E} 202 \mathrm{Q}$ mutant human acetylcholinesterase complexed with the snake-venom toxin fasciculin-II. Acta Crystallogr. 2000;56(11):1385-94.

36. Friesner RA, Murphy RB, Repasky MP, Frye LL, Greenwood JR, Halgren $\mathrm{TA}$, and et al. Extra precision glide: docking and scoring incorporating a model of hydrophobic enclosure for protein-ligand complexes. J Med Chem. 2006;49(21):6177-96.

37. Bartolini M, Bertucci C, Cavrini V, Andrisano V. Beta-Amyloid aggregation induced by human acetylcholinesterase: inhibition studies. Biochem Pharmacol. 2003;65(3):407-16.

38. Sharma AC, Kulkarni SK. Evaluation of learning and memory mechanisms employing elevated plus-maze in rats and mice. Prog Neuropsychopharmacol Biol Psychiatry. 1992;16(1):117-25.

\section{SUMMARY}

- A novel series of 4-aminopyridine bearing semicarbazones derivatives were designed, synthesized, characterized and evaluated for cognition enhancing activity along with molecular docking studies. Out of the twenty compounds only two compounds 3 and 9 demonstrated a comparable activity with that of rivastigmine. In docking studies, the hydroxyl group of one of the phenyl rings of these compounds was observed establishing H-bond with Tyr-70 which plays a dual role in the active centre. These compounds are emerged as most potent of these series which can be considered for the future drug development in search of new cognition enhancers. 


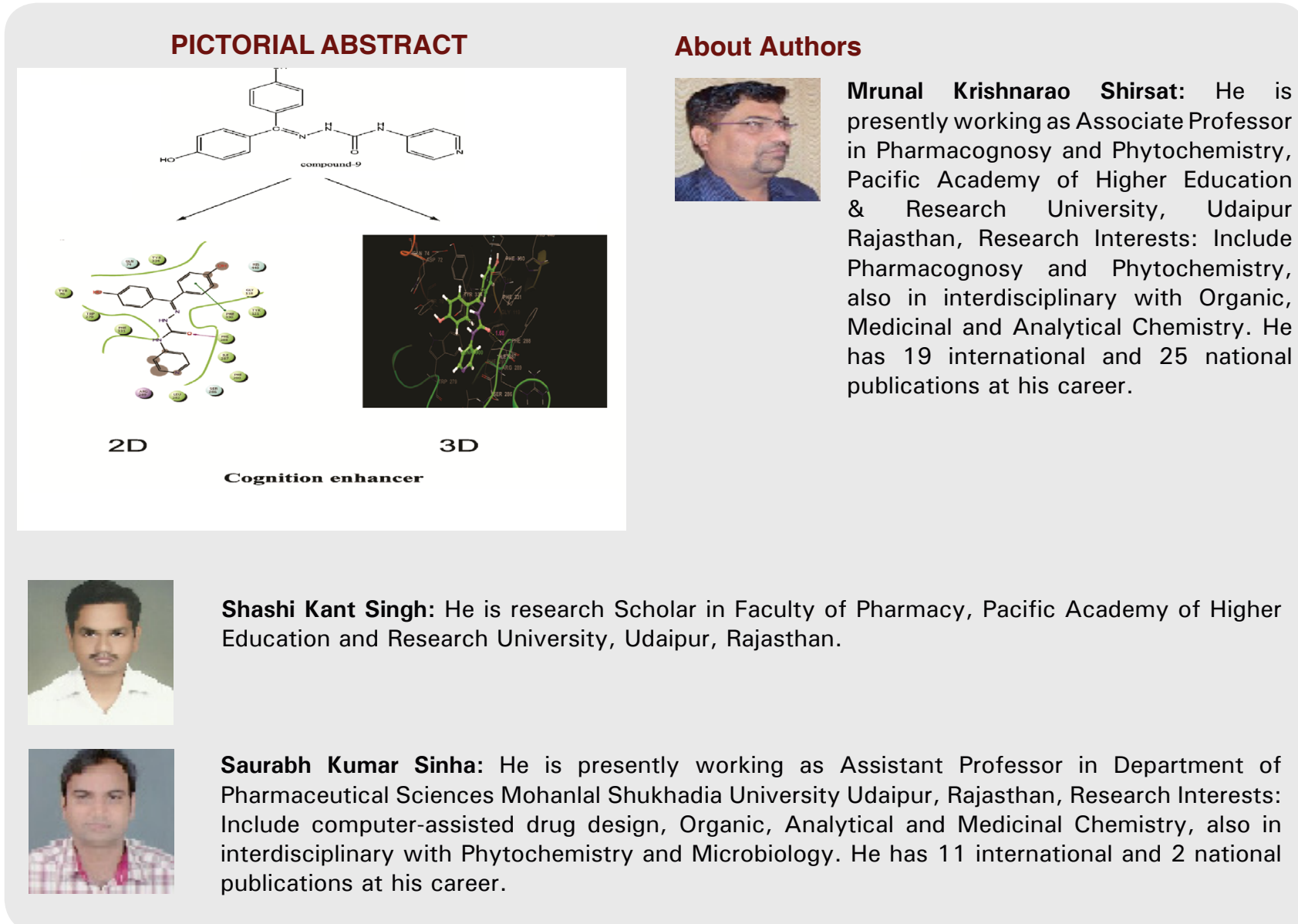

Cite this article: Singh SK, Sinha SK, Shirsat MK. Design, Synthesis and Evaluation of 4-Aminopyridine Analogues as Cholinesterase Inhibitors for Management of Alzheimer's Diseases. Indian J of Pharmaceutical Education and Research. 2018;52(4):644-54. 